\title{
Evaluation of inhibitor effect on micelium development on Fusarium oxysporum, $y$ $F$. solani, using three dosis of epazote epazote (Chenopodium ambrosioides $\mathbf{L}$.)
}

Evaluación del efecto inhibidor del desarrollo micelial en Fusarium oxysporum, $\boldsymbol{y}$ F.
solani, bajo tres dosis de extracto crudo de epazote (Chenopodium ambrosioides $\mathrm{L}$.)

\author{
MORENO-ZACARÍAS, Pedro Eduardo†* \& RAMOS-DUEÑAS, Flor Del Carmen \\ Instituto Tecnológico Superior de Salvatierra, Tecnológico Nacional de México \\ ID $1^{\text {st }}$ Author: Pedro Eduardo, Moreno-Zacarías / ORC ID: 0000-0003-4904-4824, CVU CONACYT ID: 428055 \\ ID $1^{\text {st }}$ Coauthor: Flor Del Carmen, Ramos-Dueñas / ORC ID: 0000-0002-6026-672X
}

DOI: $10.35429 / \mathrm{JESN} .2019 .15 .5 .23 .28$

Received April 26, 2019; Accepted June 30, 2019

\begin{abstract}
Using natural extract of epazote (Chenopodium ambrosioides L.), has shown to control phytopatogenic fungi (P. Aguilar et al., 2013; y J. Black Solis et al., 2017). One mililiter of ethanolic extract at concentrations of $25 \%, 50 \%, 100 \%$ diluted on sterile distilled water $(\mathrm{V}: \mathrm{V})$ has been used to inhibit micelial developement of Fusarium oxysporum, and Fusarium solani, added to PDA Petri dish under a completely randomized experimental design, a statistical analysis was carried out by means of an ANOVA and comparison test of means with Tukey's multiple range. After eight days of incubation, the outstanding inhibit effect has been observed with $100 \%$ and the average diameter of colonies was $62 \mathrm{~mm}$., has been measured on both fungi species. In contrast, $62 \mathrm{~mm}$., and 61 mm., was observed on $F$. oxysporum and $F$. solani respectively, and a statistical effect was observed $(\mathrm{p} \leq 0.05)$. With $25 \%$ and $50 \%$, micelial inhibit developement has been measured, but no statistical differences between concentrations has been calculated ( $\mathrm{p} \geq 0.05)$ for both fungi. The results suggest that ethanolic extract of epazote could be used to control both phytopathogenic fungi.
\end{abstract}

Epazote, Extract, Phytopathogenic fungi

\begin{abstract}
Resumen
El empleo de extractos naturales de epazote (Chenopodium ambrosioides L.), ha tomado un papel importante para el control de hongos fitopatógenos (P. Aguilar et al., 2013; y J. Black Solis et al., 2017) El objetivo de este trabajo fue evaluar el efecto inhibidor del crecimiento micelar en Fusarium oxysporum, y Fusarium solani, usando tres dosis de extracto crudo de epazote a: $25 \%, 50 \%, 100 \%$ diluidas en agua destilada estéril (V:V) y un testigo absoluto, incorporando $1 \mathrm{~mL}$., de la dilución en placa con PDA más el inóculo, con tres repeticiones por tratamiento. Se aplicó un análisis de varianza (ANOVA) y comparación de rango múltiple (Tukey). Posterior a ocho días de incubación, se observó un mayor efecto inhibitorio; el diámetro colonial promedio fue de 15 $\mathrm{mm}$, bajo la concentración del $100 \%$ para ambas especies; en contraste, se registró un diámetro promedio de $62 \mathrm{~mm}$ y $61 \mathrm{~mm}$., en $F$. oxysporum y $F$. solani respectivamente con el testigo absoluto; con una diferencia significativa $(\mathrm{p} \leq 0.05)$. Bajo las concentraciones de $25 \%$ y $50 \%$ se observó inhibición en el desarrollo micelial pero sin diferencias significativas $(\mathrm{p} \geq 0.05)$.Los resultados sugieren la aplicación de extracto de epazote para controlar del crecimiento miceliar $F$. oxysporum y $F$. solani.
\end{abstract}

Epazote, Extracto, Hongos fitopatógenos

Citation: MORENO-ZACARÍAS, Pedro Eduardo \& RAMOS-DUEÑAS, Flor Del Carmen. Evaluation of inhibitor effect on micelium development on Fusarium oxysporum, y F. solani, using three dosis of epazote epazote (Chenopodium ambrosioides L.). Journal of Environmental Sciences and Natural Resources. 2019, 5-15: 23-28

\footnotetext{
* Correspondence to Author (email: pemoreno@itess.edu.mx)

$\dagger$ Researcher contributing first author.
} 


\section{Introduction}

In current agriculture, the practices that refer to conserving and generating the least impact on native populations have become relevant. In this sense, the control of pathogenic organisms to crops has turned its management towards treatments with molecules of organic origin, reducing the restrictions on the use of traditional control with synthetic molecules.

Fusarium oxysporum and $F$. solani have been clearly identified as phytopathogens in chili, corn, tomato, strawberry, and many others (Hernández-Delgado, Ángel Reyes-López, Gerardo García-Olivares, Mayek-Pérez, \& Reyes-Méndez, nd; Mayens Vásquez-Ramírez \& Castaño-Zapata, 2017; Morales-López, Torres-Arteaga, Salas-Galván, et al., 2017; Nam, Park, Kim, \& Yoo, 2009).

Based on the above, controlling the invasions of these organisms has been a priority; aqueous extracts of clove spices (Eugenia caryophyllata) cinnamon (Cinnamomum zeylanicum); and Mexican oregano (Lippia berlandieri) (Rueda de León, Vargas, Muñoz, Muñoz Castellanos, \& Ochoa, 2013), phenolic extracts of chilpetin fruits (Rodriguez-Maturino et al., 2015), by Heliopsis longipes L., (Morales -Lopez, Torres-Arteaga, E., et al., 2017; Morales-López, Torres-Arteaga, Salas-Galván, et al., 2017) (Morales-López, Torres-Arteaga, Salas-Galván, et al. , 2017; Susana, Flores López, Benavides Mendoza, \& Flores Olivas, 2011), Galla chinensis, GC., And $1 \%$ tannic acid (Forrer et al., 2014),

Epazote (Chenopodium ambrosioides L.) is a plant native to Mexico used as a condiment or recognized to treat various stomach pains and intestinal parasites (Ferreira et al., 2019; Potawale et al., 2008; Vibrans, 2009).

The extract of this plant has been registered as a biochemical pesticide before the EPA (Anonymous, 2011), with antifungal activity (Jardim et al., 2010; Shah, Nisar, Suhail, \& Bacha, 2014) and its essential oils (Aguilar et al., 2013; Black Solis, Ventura Aguilar, Barrera Necha, \& Bautista Baños, 2017) have shown an antifungal activity against F. oxysporum.
This due to the presence of bioactive compounds such as ascaridol (Aguilar et al., 2013), likewise, ethanolic extracts of dried leaves of epazote (Chenopodium ambrosioides) in mature and immature state on the inhibition of in vitro mycelial growth of Colletotrichum gloeosporioides, Fusarium oxysporum, Alternaria alternata, and Botrytis cinerea proved effective to inhibit the mycelial development of these fungi (Cabrera Calderón, Rivera Rebollar, Lira Vargas, Trejo Marquez, \& Pascual Bustamante, 2016). At a concentration of $100 \mu \mathrm{g} / \mathrm{L} .$, C. ambriosioides leaf oils showed an antifungal effect, against $\mathrm{F}$. oxysporum and other fungi that invade stored grains (Kumar, Mishra, Dubey, \& Tripathi, 2007).

\section{Materials and Method}

\section{a) Obtaining crude extract.}

The plant material that was used to obtain essential oils were previously dehydrated epazote leaves, being exposed to the environment for two continuous weeks. In the Soxhlet, 20 grams of the plant material plus $350 \mathrm{ml}$ of absolute ethanol as solvent were placed (Aldrich Chemical Co. Mexico, DF) (Cabrera Calderón et al., 2016; Ferreira et al., 2019; Kumar et al., 2007; Susana et al., 2011); The packing column was formed by the previous mixture covered with sterile cotton in an Italian type glass distiller and kept boiling $\left(97^{\circ} \mathrm{C}\right)$ for $4 \mathrm{~h}$. The essential oils were stored in amber bottles at room temperature; three extractions were made obtaining a total of 550 $\mathrm{ml}$ of solution. To remove the solvent from the extract, a simple distillation was performed, obtaining $18 \mathrm{ml}$ of essential oils.

b) Dosage formulation:

Three different doses and one absolute control were used as treatments (table 1), by the method of diluting ethanolic extract in sterile distilled water, in $\mathrm{v} / \mathrm{v}$ ratio, in $50 \mathrm{ml}$ flasks. In total, $17.5 \mathrm{ml}$ of ethanol extract were used (Aguilar-Alonso, Navarro-Cruz, SanchezFlores, Meneses-Sánchez, \& Avila-Sosa, 2013). 


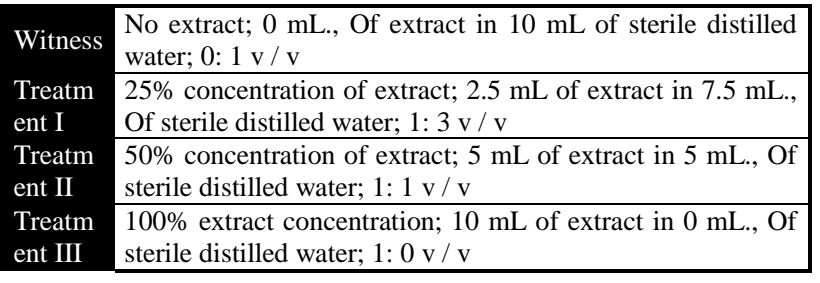

Table 1 Concentration of $C$. ambriosioides extracts

c) Mycelial growth inhibition assays:

The trial was conducted with strains of Fusarium solanii, and F. oxysporum, which were kindly provided by Dr. Marcia M. Martínez S., professor-researcher of the IIAS career at ITESS. The inhibitory effect of the ethanolic extract was determined by the agar dilution method (Black Solis, 2017) which consisted of mixing $1 \mathrm{~mL}$. Of each solution and its ethanolic concentrate of C. ambriosioides, stirring each Petri dish with liquid PDA and leaving solidify. Subsequently, a sample of each strain was taken with a handle, depositing it in the middle. It was allowed to incubate in dark conditions at $27^{\circ} \mathrm{C}$ in an incubator (Memmert brand mod. IFE 400)Registro de datos. After inoculation, the diameter of the colonies was recorded, every two days (Zavala, Herrera, Lara, \& Garzón, 2017), the measure was taken with a vernier and recorded in respective tables.

d) Data analysis.

An analysis of variance (ANOVA) and multiple range comparison (Tukey) was applied applying a level of significance of 5\% (Hernández-Ochoa, Macĺas-Castanãeda, Nevárez-Moorillón, Salas-Muñoz, \& SandovalSalas, 2012). The statistical package used was the MINITAB ® version 2017 program.

\section{Results}

In vitro tests showed a greater effect of inhibition of mycelial development, with the extract concentration of $100 \%$ (Figure 1). Inhibition is observed continuously during the three epochs of the data record (Graph 1; Graph 2 ). the average colonial diameter was $15 \mathrm{~mm}$, in contrast to the control treatment $(0 \%$ crude extract concentration), with an average diameter of $62 \mathrm{~mm}$ and $61 \mathrm{~mm}$ being observed, in contrast, under the concentrations of $25 \%$ and $50 \%$, the inhibition continues observed, (table 2), but under the last day of registration, the differences are less in magnitude.

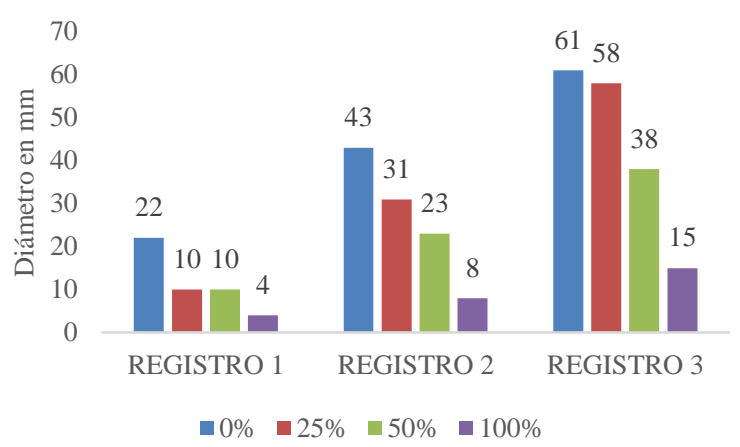

Graphic 1 Colonial growth diameter in $F$. oxysporum

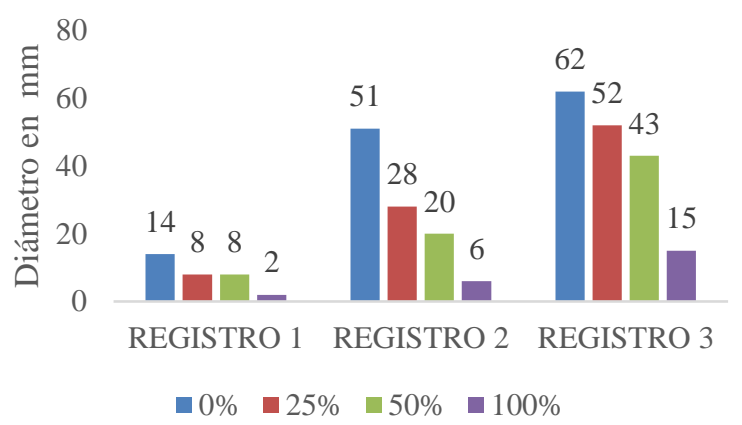

Graphic 2 Colonial growth diameter in $F$. solani

\begin{tabular}{|l|r|r|r|r|r|r|}
\hline $\begin{array}{c}\text { Concentration } \\
\text { of ethanolic } \\
\text { extract }\end{array}$ & \multicolumn{3}{|c|}{$\begin{array}{c}\text { Fusarium } \\
\text { oxysporum } * * *\end{array}$} \\
\hline $0 \%$ & 2 & 4 & 6 & 2 & 4 & 6 \\
\hline $25 \%$ & 14 & 51 & 62 & 22 & 43 & 61 \\
\hline $50 \%$ & 8 & 28 & 52 & 10 & 31 & 58 \\
\hline $100 \%$ & 8 & 20 & 43 & 10 & 23 & 38 \\
\hline$*$ mycelial diameter in millimeters \\
\hline * Average of three repetitions \\
\hline
\end{tabular}

Table 2 Inhibition of micellar development (in $\mathrm{mm}$ ) of Fusarium oxysporum and F. solani at four doses of epazote crude extract

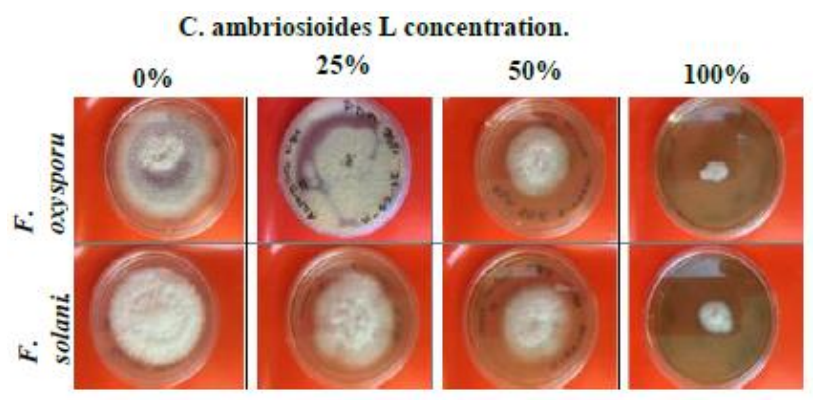

Figure 1 Inhibition of mycelial development in $\mathrm{F}$. oxysporum and F. solani at four levels of ethanolic extract of C. ambriosioides

The statistical analysis showed a significant difference $(\mathrm{p} \leq 0.05)$ confirming that the $100 \%$ concentration showed the greatest effect of micellar inhibition (table 3 and table 4). 


\begin{tabular}{|lr|r|r|r|r|}
\hline Source of the variation & $G L$ & $S C$ & $M C$ & $F$ & $P$ \\
\cline { 2 - 7 } Extract Concentration & 3 & 192.917 & 64.306 & 10.87 & 0.003 \\
\hline Error & 8 & 47.333 & 5.917 & & \\
Total & 11 & 240.25 & & & \\
\hline
\end{tabular}

Table 3 Variance analysis. Inhibition of micellar development (in $\mathrm{mm}$ ) of Fusarium oxysporum at four doses of epazote crude extract

\begin{tabular}{|l|r|l|l|l|l|}
\hline Source of the variation & $G L$ & $S C$ & $M C$ & $F$ & $P$ \\
\hline Extract Concentration & 3 & 516.25 & 172.08 & 9.79 & 0.005 \\
\hline Error & 8 & 140.67 & 17.58 & & \\
Total & 11 & 656.92 & & & \\
\hline
\end{tabular}

Table 4 Variance analysis. Inhibition of micellar development (in $\mathrm{mm}$ ) of Fusarium solani at four doses of epazote crude extract

\section{Discussion}

The effect of the concentration of epazote extract, is observed within each organism tested, that is, there is an inhibition in the mycelial development in F. oxysporum and F. solani, proportional to the increase in the concentration of the extract (table 3 and table 4). This same response is obtained when evaluating ethanolic extracts of dried leaves of epazote, in mature and immature state, under in vitro conditions in F. oxysporum and three other phytopathogenic fungi, the concentrations of 2000 and $3000 \mathrm{ppm}$ with the mature epazote inhibited by $100 \%$ mycelial development as well as the concentration of $3000 \mathrm{ppm}$ of immature epazote extract (Cabrera Calderón et al., 2016), in this work, commercially acquired epazote leaves were used fresh, and coincides that the highest concentrations they also generated the inhibition of the fungus development as well as the decrease in sporulation, which was also observed when using aqueous extracts of $\mathrm{C}$. ambriosioides at a concentration of $2 \%$ totally inhibited the development and sporulation in Fusarium oxysporum f. sp. lycopersici (FOL) and F. solani (Vazquez Covarrubias, Montes Belmont, Jiménez Pérez, \& Flores-moctezuma, 2013).

Likewise, essential oils of C. ambrosioides showed an effect against Fusarium oxysporum by inhibiting the mycelial development of $97.3 \%$ at a concentration of 176.5 $\mu \mathrm{L} \mathrm{EO} \mathrm{/} \mathrm{L} \mathrm{air} \mathrm{after} 72 \mathrm{~h}$ of exposure (Jaramillo C., Edisson Duarte, \& Delgado, 2012 ), similar to the results of this work. Studies by Cabrera Calderón et al. (Cabrera Calderón et al., 2016) showed that at 2000 and 3000 ppm of mature and immature extract of epazote.
An inhibition of micellar development was obtained at levels greater than $75 \%$. (Flores-Pacheco, 2017). Similarly, a reaction was demonstrated in the inhibition of micellar development in F. oxysporum using aqueous extracts of clove, cinnamon and oregano (Rueda de León et al., 2013)

\section{Acknowledgment}

We thank Ing. Maribel Ramos Aguilar for her support in the Chemistry Laboratory of the Higher Technological Institute of Salvatierra.

\section{Conclusions}

The results suggest that the application of $\mathrm{C}$. ambriosioides extract can function as an inhibitor of the micellar growth of these fungi.

\section{References}

Aguilar-Alonso, P., Navarro-Cruz, A. R., Sanchez-Flroes, A. B., Meneses-Sánchez, M. de la C., \& Avila-Sosa, R. (2013). Efecto antifúngico de extractos de plantas originarias del Estado de Puebla sobre Colletottichum gleosporoides. CIENCIA UAT, 7(2), 6-11.

Aguilar, P., Navarros, A., Sanchez, B., Meneses, M., Avila, R., Gonzales, A., ... Article, O. (2013). Efecto antifúngico de extractos de plantas originarias del Estado de Puebla sobre Colletotrichum gloeoporioides. CIENCIA UAT, 16(3), 6-11.

Anonimo. (2011). Extract of Chenopodium ambrosioides near ambrosioides (599995) Fact Sheet.

Black Solis. (2017). Caracterización química, variabilidad composicional y modelamiento matemático del efecto de aceites esenciales en Alternaria alternata. Revista Mexicana de Fitopatología, Mexican Journal of Phytopathology, 35(2), 204-226. https://doi.org/10.18781/r.mex.fit.1612-5

Black Solis, J., Ventura Aguilar, R. I., Barrera Necha, L. L., \& Bautista Baños, S. (2017). Caracterización química, variabilidad composicional y modelamiento matemático del efecto de aceites esenciales en Alternaria alternata. Revista Mexicana de Fitopatología, Mexican Journal of Phytopathology, 35(2), 204-226. https://doi.org/10.18781/r.mex.fit.1612-5 
Cabrera Calderón, S., Rivera Rebollar, R., Lira Vargas, A., Trejo Marquez, M., \& Pascual Bustamante, S. (2016). Efecto antifúngico de extracto de epazote (Chenopodium ambrosioides) sobre hongos postcosecha. Investigación y Desarrollo En Ciencia y Tecnología de Alimentos, 1(2), 379-384.

Ferreira, T. M. S., Santos, J. A. do., Modesto, L. A., Souza, L. S., Santos, M. P. V. do., Bezerra, D. G., ... de Paula, J. A. M. (2019). An eco-friendly method for extraction and quantification of flavonoids in Dysphania ambrosioides. Brazilian Journal of Pharmacognosy, 29(2), 266-270. https://doi.org/10.1016/j.bjp.2019.01.004

Flores-Pacheco, J. A. (2017). Antagonismo in vitro de hongos endófitos para su uso en el biocontrol de enfermedades forestales. Revista Científica de FAREM-Estelí, (23), 58-71. https://doi.org/10.5377/farem.v0i23.5475

Forrer, H. R., Musa, T., Schwab, F., Jenny, E., Bucheli, T. D., Wettstein, F. E., \& Vogelgsang, S. (2014). Fusarium head blight control and prevention of mycotoxin contamination in wheat with botanicals and tannic acid. Toxins, 6(3), 830-849. https://doi.org/10.3390/toxins6030830

Hernández-Delgado, S., Ángel Reyes-López, M., Gerardo García-Olivares, J., Mayek-Pérez, N., \& Reyes-Méndez, N. (n.d.). Incidencia de Hongos Potencialmente Toxígenos en Maíz (Zea mays L.) Almacenado y Cultivado en el Norte de Tamaulipas, Méxicomx. MatamorosReynosa.

Hernández-Ochoa, L., MacÍas-Castañeda, C. A., Nevárez-Moorillón, G. V., Salas-Muñoz, E., \& Sandoval-Salas, F. (2012). Antimicrobial activity of chitosan-based films including spices' essential oils and functional extracts. CYTA - Journal of Food, 10(2), 85-91. https://doi.org/10.1080/19476337.2011.576434

Jaramillo C., B. E., Edisson Duarte, R., \& Delgado, W. (2012). Bioactividad del aceite esencial de Chenopodium ambrosioides colombiano. Revista Cubana de Plantas Medicinales, 17(1), 96-97.
Jardim, C. M., Jham, G. N., Dhingra, O. D., \& Freire, M. M. (2010). Chemical Composition and Antifungal Activity of the Hexane Extract of the Brazilian Chenopodium ambrosioides L. J. Braz. Chem. Soc., 21(10), 1814-1818.

Kumar, R., Mishra, A. K., Dubey, N. K., \& Tripathi, B. (2007). Evaluation of Chenopodium ambriosioides oil as potential source of antifungal, antiaflatoxigenic and antioxidant activity Rajesh Kumar, Ajay Kushmar Mishra, N. K. Dubey, y. B. Tripathi International food of microbology 115 (2007) 159-164. International Food of Microbology, 115, 159-164.

Mayens Vásquez-Ramírez, L., \& CastañoZapata, J. (2017). Manejo integrado de la Marchitez por Fusarium. . U.D.C.A Act. \& Div. Cient., 20(2), 12. Retrieved from http://www.scielo.org.co/pdf/rudca/v20n2/v20n 2a14.pdf

Morales-López, G., Torres-Arteaga, I. C., E., S.-G. M., Méndez-Valencia, D., CarreñoAguilera, G., Balzar Vera, J. C., \& RamosGarcía, A. (2017). Evaluación de actividad fungicida de extractos crudos de raíces de Heliopsis longipes contra Alternaria sp., Fusarium sp y Rhizopus sp. Investigación y Desarrollo En Ciencia y Tecnología de Alimentos, 2, 194-198.

Morales-López, G., Torres-Arteaga, I., SalasGalván, M. E., Méndez-Valencia, D., CarreñoAguilera, G., Baltazar Vera, J. C., \& RamosGarcía, A. (2017). Investigación y Desarrollo en Ciencia y Tecnología de Alimentos EVALUACIÓN DE ACTIVIDAD FUNGICIDA DE EXTRACTOS CRUDOS DE RAÍCES DE Heliopsis longipes CONTRA Alternaria sp, Fusarium sp Y Rizophus SP. 2, 194-198.

Nam, M. H., Park, M. S., Kim, H. G., \& Yoo, S. J. (2009). Biological control of strawberry Fusarium wilt caused by Fusarium oxysporum f. sp. fragariae using Bacillus velezensis BS87 and RK1 formulation. Journal of Microbiology and Biotechnology, 19(5), 520-524. https://doi.org/10.4014/jmb.0805.333

Potawale, S. E., Luniya, K. P., Mantri, R. A., Mehta, U. K., Sadiq, M. D., Waseem, M. D., ... Deshmukh, R. S. (2008). Chenopodium ambrosioides: an ethnopharmacological review. Pharmacologyonline, 2, 272-286. 
Rodriguez-Maturino, A., Troncoso-Rojas, R., Sánchez-Estrada, A., González-Mendoza, D., Ruiz-Sanchez, E., Zamora-Bustillos, R., ... Aviles-Marin, M. (2015). Efecto antifúngico de extractos fenólicos y de carotenoides de chiltepín (Capsicum annum var. glabriusculum) en Alternaria alternata and Fusarium oxysporum. Revista Argentina de Microbiologia, $\quad 47(1), \quad 72-77$. https://doi.org/10.1016/j.ram.2014.12.005

Rueda de León, I. C., Vargas, R. C., Muñoz, E. S., Muñoz Castellanos, L. N., \& Ochoa, L. H. (2013). Actividad Antifúngica in vitro de Extractos Acuosos de Especias contra Fusarium oxysporum, Alternaria alternata, Geotrichum candidum, Trichoderma spp., Penicillum digitatum y Aspergillus niger. (Spanish). Revista Mexicana de Fitopatología, 31(2), 105112.

Shah, H., Nisar, M., Suhail, M., \& Bacha, N. (2014). Antimicrobial studies of the crude extracts from the roots of Chenopodium ambrosioides Linn . African Journal of Microbiology Research, 8(21), 2099-2104. https://doi.org/10.5897/AJMR2013.5548

Susana, Flores López, M. L., Benavides Mendoza, A., \& Flores Olivas, A. (2011). Actividad Inhibitoria del Extracto de Heliopsis longipes Sobre Fusarium oxysporum f. sp lycopersic. Revista Mexicana de Fitopatología, 29(2), 146-153. Retrieved from http://www.scielo.org.mx/scielo.php?pid=S018 5 -

33092011000200006\&script=sci_arttext\&tlng= $\mathrm{pt}$

Vazquez Covarrubias, D. A., Montes Belmont, R., Jiménez Pérez, A., \& Flores-moctezuma, H. E. (2013). Aceites Esenciales y Extractos Acuosos para el Manejo in vitro de Fusarium oxysporum f. sp. lycopersici y $\mathrm{F}$. solani. Revista Mexicana de Fitopatología, 31(2), 170179.

Vibrans, H. (2009). Chenopodiaeae. Chenopodium graveolens Willd. Retrieved July 11, 2019, from Malezas de México. website: http://www.conabio.gob.mx/malezasdemexico/ chenopodiaceae/chenopodiumgraveolens/fichas/ficha.htm
Zavala, R., Herrera, J., Lara, A. S., \& Garzón, D. L. (2017). Evaluación de la toxicidad aguda de un extracto alcohólico de hojas de epazote (Chenopodium ambrosioides). Spei Domus, 12(24). https://doi.org/10.16925/sp.v12i24.1890 